\title{
PRIMARY CULTURE OF HEPATIC CELLS FROM Pygoscelis adelie EMBRYO*
}

SALVO, L.M. ${ }^{1}$; RICHARTZ, R.R.T.B. ${ }^{2}$; JOINEAU, M.E.G. ${ }^{2}$; PATRÍCIO, M.A.C. ${ }^{2}$; MALUCELLI, M.I.C. ${ }^{3}$; SUGIZAKI, M. ${ }^{3}$; BRITO, A.M.; SILVA DE ASSIS, H.C. ${ }^{4}$; BACILA, M. ${ }^{3}$

${ }^{1}$ Doutoranda, Faculdade de Medicina Veterinária e Zootecnia, USP;

${ }^{2}$ Centro de Diagnóstico Marcos Enrieti - Curitiba-PR;

${ }^{3}$ Pontifícia Universidade Católica do Paraná, PUCPR;

${ }^{4}$ Departamento de Farmacologia, Universidade Federal do Paraná, UFPR.

The aim of the present research work is to establish the methodology for the primary culture of hepatic cells from Pygoscelis adelie embryos. Cultivation of cells from different animal species is becoming very important by being a fundamental biological material for virology and endocrinology studies and, more recently, as a suitable model for the study in vitro of oxidative stress and the effect of enviornmental contaminants. During the XVIII Brazilian Antarctic Expedition, embryonated eggs from Pygoscellis adelie were collected. The eggs were previously estrilized and after that the embryos were collected by means of a forceps and placed in a Petri's dish containing buffered Hank's solution added with antibiotics. The organs, kuver, retina and muscle, were excised and washed twice with PBS in order to remove erythrocytes. Following this step, the liver has been cut ein small fragments and trypsinized according to the methodology for primary cell culture adopted by SALVO et al., (2000). After the establishment of cell viability carried out with Tripan Blue, the cells wwere smeared in dishes for cultivation and placed in a $\mathrm{CO}_{2}$ ovenat $37^{\circ} \mathrm{C}$. The cells began the process of adhesion and differenciation in 48 hours. After the confluence of $70 \%$ of the monolayer, the cells were trypsinized and placed in a freezing solution containing $40 \%$ SFB, $10 \%$ DMSO and $50 \%$ of the culture medium F10-199. The cells were then taken in liquid nitrogen from the Antarctic to our Labortory in Brazil in order to continue this important research.

Key Words: Cell culture; penguin embryo; hepatic cells; Pygoscellis adelie *With a suport from CNPq - Programa Antártico Brasileiro. 